\title{
Expansion of Fairtrade Products in Chinese Market
}

\author{
Kathryn Gomersall \\ The University of Melbourne, Australia \\ E-mail: k.gomersall@student.unimelb.edu.au
}

Mark Yaolin Wang

Melbourne School of Land and Environment, the University of Melbourne

Australia

E-mail: myw@unimelb.edu.au

\author{
Received: November 18, $2011 \quad$ Accepted: December 2, $2011 \quad$ Published: January 1, 2012 \\ doi:10.5539/jsd.v5n1p23 \\ URL: http://dx.doi.org/10.5539/jsd.v5n1p23
}

\begin{abstract}
The consumption of Fairtrade goods in the developed world has gained in popularity over the last two decades, but Fairtrade products have only recently entered markets in China. While Western consumers' attitudes to consumption of Fairtrade products have been well studied, little attention has been paid to the arrival of such concepts to the Chinese domestic market. This paper aims to begin to fill this gap by investigating Chinese consumers' level of awareness and understanding of the Fairtrade concepts and whether the level of willingness to pay extra for Fairtrade products is associated with consumers' socioeconomic characteristics. This paper reveals that the current level of awareness and understanding of Fairtrade principles in China is low. The level of willingness to pay extra is not closely associated with income level but with level of awareness and understanding of Fairtrade principles.
\end{abstract}

Keywords: Market, Consumers, Fairtrade products, Awareness, China

\section{Introduction}

Fairtrade is a worldwide voluntary certification scheme that seeks better prices, decent working conditions, local sustainability and fair terms of trade for workers in the developing world (Fairtrade Australia \& New Zealand, 2011). It is a relatively new concept: the first Fairtrade products entered the major western markets in the late 1980s (Witkowski, 2005). The initial idea was that cooperatives or producers in the developing world sell their products to licensed Fairtrade exporters, importers or buyers, who process and package the goods and distribute them to companies and retailers in the developed world (Fairtrade Foundation, 2005). Current Fairtrade consumers in the major Fairtrade markets, such as Europe, the US, Australia and New Zealand are highly principled people (Watterson, 2008). Their level of awareness and understanding about Fairtrade is generally high. For example, 90 percent of UK consumers recognise the Fairtrade mark and one in four regularly buys several products carrying the label (Fairtrade Foundation, 2011). Motivation for consumers to purchase brands with the Fairtrade label comes from a personal responsibility to help producers and workers as this is seen as a more ethical and fair means of consumption (Fairtrade Foundation, 2011). Therefore, consumers seek to use their power in the market as Fairtrade consumers to balance what they see as the social and environmental injustices of the conventional market system, caused by large corporate enterprise (Doran, 2010).

China has recently become a Fairtrade tea-producing country; however Fairtrade goods (such as tea and coffee) are sold in only a few cities on a small scale, such as in small coffee retailers or foreign companies such as Marks \& Spencer (The Green Room, 2011). The existing literature has not paid attention to this new development in China. There is no research about Chinese consumers' understanding of the Fairtrade concept or willingness to accept its principles. This paper attempts to fill this research gap by examining Chinese Fairtrade consumers' level of understanding of the Fairtrade concept, including principles such as fair working conditions, empowerment and environmental sustainability. Consequently, Chinese consumer's willingness to pay a premium for these products, and how the level of willingness to pay is associated with customers' level of understanding and income, will be determined. 
Data used in this paper were collected in China in July 2010. The case study site selection is based on the following considerations. In mainland China, Fairtrade products have entered the market in four cities, beginning in 2008. There are a total of eight Fairtrade stores located in four Chinese cities: three in Shanghai, three in Suzhou (Jiangsu province), one in Hangzhou (Zhejiang province) and one in Guangzhou (Guangdong province) (The Green Room, 2011). The authors conducted a survey and interviews in all stores in both Shanghai and Suzhou. Shanghai's three stores are Marks \& Spencer (a foreign-owned department store), Graz Café (a Chinese-owned café in the Nanjing Road district) and West Well (a Chinese-owned café in the tourist district of Zhujiajiao). Suzhou's three stores are The Green Room Café (a Chinese-owned café in the old city tourist district), Summit Lifestyle Supermarket and Water Lotus Vegetarian Restaurant. All Fairtrade stores in Suzhou are Chinese-owned. During the survey, 103 questionnaires were completed: of these, 81 were in-store consumers, 19 were store staff and three were café owners.

The survey questionnaire was split into three parts. The first section covered the respondents' awareness of Fairtrade: if they had heard of it or seen the label before and if, when and where they had ever bought any products. The second section covered the respondents' understanding of the principles of Fairtrade by asking them to select the Fairtrade-aligned answer from three multiple choice answers. The principles of Fairtrade included in the survey were fair pricing, workers' rights, community empowerment and environmental sustainability. The third section covered the demographic information of the respondent including age, education level, occupation and income. Demographic data are used to analyse the relationship between levels of awareness and understanding and personal characteristics.

In order to gain more in-depth information, nine semi-structured interviews were also conducted at the stores. Each interview ran for approximately 30 minutes. Questions were asked regarding respondents' understanding of the four principles of Fairtrade that featured in the questionnaire and the implications these principles would have for China. Questions also covered topics such as respondents' attitudes towards the pricing of Fairtrade goods and the added costs of production and assessed the barriers that Fairtrade may experience in trying to enter the Chinese market. A local Chinese translator was present to ensure against language barriers. Of the nine interviewees, three were the owners of small cafés (West Well, Graz Café and The Green Room), three were staff at Marks and Spencer and three were customers at Marks and Spencer. The last interview was conducted over the internet by the distributor of Fairtrade goods to the cafes in China who lives in Beijing.

The remainder of the paper is divided into four sections. The first section reviews current research into Fairtrade consumption in the developed world. The second section presents survey data results, with a descriptive analysis of the level of understanding of Fairtrade in the sample. The third section discusses respondents' willingness to pay, followed by a brief conclusion.

\section{The Literature on Fairtrade}

The Fairtrade concept was designed in response to growing inequalities created by the conventional market system. In conventional trade, the market is dominated by a few large multinational companies who can take advantage of economies of scale, such as increasing agro-farming yields with high chemical inputs to large plantations, and by paying workers in these plantations poverty wages (Fairtrade Foundation, 2005). The Fairtrade Foundation (2008) argues that the effect is to push down prices, creating a pricing war which will push smaller competitors out of the market. Smaller producers have much less power in the market as their unit costs per item are much higher and they cannot produce the same volumes. The Fairtrade Foundation (2011) has also shown that large retail chains retain power over their suppliers in the market with the huge volumes that they purchase. As a consequence, they are able to pass risks and costs back down the supply chain to the more vulnerable farmers who are unable to protect themselves against poverty wages and inadequate working conditions.

The introduction of Fairtrade, a voluntary certification scheme, is intended to counter such problems. For example, Fairtrade Australia and New Zealand (2011) state that Fairtrade intends to empower communities to gain from participating fairly in a global trading market. The distribution of the rewards from such trade is done in an equitable manner, contributing to community development. Fairtrade aims to make development more sustainable by providing ongoing and equitable access to markets instead of temporary donor funds. The injustices of the global trading system are remedied through fairer pricing of goods (through a price premium), better working conditions and more environmentally sustainable development.

Auger et al. (2003) have found that as a consequence of these fairer arrangements, there is an increase in consumer activism with respect to the products of multinational corporations. Social movements such as Fairtrade have made the public more aware of the influence consumers have over the producers of their goods, 
whether corporate or not, and to use this influence as a platform for social activism - as supermarket socialists. Consumer behaviour is seen as the lifeblood of all commercial activity and these everyday actions are the basis for new grassroots social movements. In fact, according to Auger et al. (2003), with adequate information available regarding the ethical features of products, consumers are exhibiting a trend towards buying socially responsible goods. In fact, consumers are showing a willingness to pay a considerable mark-up on products that have features that support the social issues that they value. Producers and consumers are connected through the Fairtrade label which signifies consumer's willingness to pay extra for ethically-sourced goods (Fairtrade Foundation, 2008). Doran (2010) suggests Fairtrade consumers use their power in the market to tackle the social and environmental problems of the global trading system. They are ultimately dissatisfied with the poor returns earned by small producers given the handsome mark-up awarded to retailers and middlemen. Fair pricing shortens complex supply chains and returns around 40 percent of the purchase price back to the producer (Doran, 2010).

Consumers' behaviour and willingness to pay for Fairtrade products are related to ethical consumerism, defined as buying products that are made ethically by companies that act ethically, or using the social components of a company's business process (i.e. environmental protection or workers' conditions), for business success (Freestone \& McGoldrick, 2007). Here, consumers' values play an important role in ethical consumption behaviour, as goods and services are selected with value-related goals in mind (Freestone \& McGoldrick, 2007). Doran (2009) concludes that the values of advocates of Fairtrade have an inclination towards universalism, which is referred to as "broadmindedness, wisdom, social justice, equality, a world at peace, a world of beauty, unity with nature and protecting the environment" (Schwartz, 2009). These values align with the Fairtrade values of social justice and equality for poorer communities in developing countries.

Watterson's (2008) research has revealed that Fairtrade consumers in developed countries are highly principled people. For example, Fairtrade consumers in New Zealand are willing to support a principled cause regardless of whether it yields practical results. They believe the sorts of altruistic relationships they build with producer communities through Fairtrade are necessary to being a human being. Fairtrade reduces the social distance between themselves and those who produce their food, which redefines the relationship between producer and consumer. Watterson (2008) believes it is through the capitalist exchange that commodities like food become abstracted from their human and natural roots and price becomes the dominant characteristic. Therefore, Fairtrade re-humanises this relationship.

Figure 1 describes the process in which consumers are motivated to participate in ethical consumerism. When consumers' awareness and understanding reach certain levels, they are prepared to participate in ethical activities. According to MPG International (2004), this particular model can be applied to various forms of activity including energy (production, consumption and climate change), waste (reduction, re-use, recycling and disposal), transport, pollution (air, soil and groundwater), resource consumption, social exclusion (disadvantage), health and safety, pesticides and organic food stuffs, labour security, human rights and business ethics. Figure 1 is a generic model that can be used to describe the behaviour change process that consumers go through in order to become more ethical consumers. Moreover, the Fairtrade concept incorporates some of the issues outlined above including labour security, human rights and pesticides and organic food stuffs.

Trust plays an important role in ethical consumerist decision-making (Castaldo et al., 2009). Due to information asymmetries, customers need to trust retailers that they will fulfil their obligations to developing country producers. Although consumers may harbour positive feelings towards ethical consumption they may have doubts about the effectiveness of their actions (d'Astous \& Mathieu, 2008). Castaldo et al. (2008) concluded that trust must come from the concept itself: information must be produced regarding farmers' participation and the benefits they have reaped as a result of this participation. The Fairtrade Labelling Organisation (FLO) acts as a mediator for this trust in the marketplace.

There are however numerous difficulties in marketing Fairtrade goods. As the number of Fairtrade products in the market grew, the Fairtrade Labelling Organisation (FLO) International was established in 1997 to harmonise product standards and certification under one global umbrella (FLO, 2011). However, as one case study in the US shows, ethical consumers still face confusion when buying Fairtrade goods as there are numerous labels and logos from organisations that have similar sorts of certification schemes as Fairtrade (Wynne, 2008).

Based on the existing literature, four major aspects of Fairtrade can be identified. The first is that consumers are willing to pay more for ethically sourced goods in order to balance the injustices created by unfair pricing in the conventional trading market (Fairtrade Australia \& New Zealand, 2011). The remaining three aspects are mainly based on Nelson and Pound's (2009) work. The second concerns workers rights, including social rights, training 
opportunities, non-discriminatory employment practices, conditions of employment exceeding legal minimum requirements, adequate occupational health and safety conditions and sufficient facilities for the workforce to distribute and manage the Fairtrade price premium acquired specifically for community development projects. The third aspect is social empowerment. This includes producer self-confidence, self-esteem and peace of mind. It further includes having access to knowledge of producer markets and export markets, producer knowledge of Fairtrade, social cohesion and the ability to resolve disputes, networking and community participation in decision-making. The final aspect is environmentally sustainable development. This includes minimum and safe use of agrochemicals, proper and safe management of waste, maintenance of soil fertility and water resources, no use of genetically modified organisms. Environmental impact assessments are required on all activities to minimise the harmful environmental impacts of production. Fairtrade also encourages the use of organic methods of production, which have the potential to not only improve environmental conditions but also improve the health of workers. These four aspects are the foundation of the Fairtrade concept and as a consequence are used as criteria to assess Chinese consumers' awareness of and level of understanding of Fairtrade. Level of understanding is measured by how many aspects consumers know the definition of.

While developed country consumers are becoming more aware of Fairtrade and its role in remedying the injustices of the global trading market, the attitudes of Chinese consumers is yet to be documented. The literature above contributes that western consumers of Fairtrade goods are principled people - they are altruistic and pursue values that support social cohesion and fairness. Fairtrade consumerism provides the opportunity for these people to participate in a form of supermarket socialism where they can make choices that will send a message to the system that violates their sense of social justice. With adequate information and education regarding the injustices of the global trading system and the Fairtrade mechanism that aims to remedy it, consumers will show a willingness to pay more for goods in order to rectify their sense of social justice. The question is whether Chinese consumers will agree with their western counterparts? The literature discusses many problems that might hinder this outcome. These may also apply to the Chinese consumer market? This paper will try to establish the level of awareness and understanding of Fairtrade and the willingness of Chinese consumers to buy Fairtrade goods using the four dominant Fairtrade aspects discussed above. These principles however are not an exhaustive description of the Fairtrade concept.

\section{Chinese Consumers' Awareness and Understanding of Fairtrade}

Fairtrade has played a prominent role in raising consumer awareness of the working conditions of the producers of the products they purchase. However the level of awareness and understanding that consumers have of the concepts of Fairtrade is crucial to whether they make ethical purchasing decisions. Our survey data was sorted into five groups according to how well respondents understood the four key Fairtrade concepts: no understanding (those with no correct answers), limited understanding (those with 1/4 of correct answers), moderate understanding (those with half the correct answers), good understanding (those with $3 / 4$ correct answers) and complete understanding (those with 100percentcorrect answers). Table 1 shows that Chinese customers have a limited level of understanding of Fairtrade. Nearly three quarters of the respondents could not give more than two correct answers regarding the four key issues relating to Fairtrade and only two out of 103 respondents had a complete understanding.

The distribution of correct answers to these four questions also varies. Overall, about 55.3 percent of the surveyed population has heard of Fairtrade. This is a fairly low result considering that all surveyed were customers of Fairtrade stores and as a consequence were exposed to Fairtrade products. The most well understood question was the principle of environmental sustainability. In fact, 76 percent of responses provided the correct answer for the Fairtrade dimension of environmentally sustainable farming. Even the group with limited understanding had 69 percent correct answers to this question. By contrast, the respondents had a poor understanding of community empowerment. In fact, this principle had the lowest proportion among all questions and all groups (apart from the group with complete understanding). Only 16 percent of respondents understood the Fairtrade principle of community empowerment. This poor understanding is further confirmed by the fact that no respondents were able to elaborate on their understanding of empowerment beyond workers improving their quality of life through employment and higher incomes. With respect to the questionnaire, our interview shows that the most popular answer to the empowerment question, with 61 out of 103 responses, was the "neo-liberal" type answer: that tea product should become competitive in global markets so that tea farmers can become prosperous. This answer may reflect the relative affluence of the sample, which was predominately business graduates working in Shanghai and Suzhou (will be discussed below). They may feel that a more open, market-driven economy has empowered them to become prosperous. 
Education level was then tested to determine its influence on consumers' level of understanding. During our fieldwork in both Shanghai and Suzhou, we found that the majority of the customers who were surveyed in the Fairtrade stores were well dressed. In fact, fairtrade stores in Chinese cities are not for low income Chinese. Like customers in other coffee stores in urban China, the customers are all uent business and student segments of the population with relatively higher education backgrounds ( $\mathrm{Li}, 2007)$. Our survey shows that about 60 percent of respondents hold bachelor degrees or higher. Among the relatively well-educated customers, a positive correlation between level of understanding and level of education can be identified (see Table 2). The higher, the education level of the respondent, the better, their level of understanding of the Fairtrade concept. The people with complete understanding all had tertiary education. The proportion of respondents with tertiary education who answered at least half of the questions correctly was over 66 percent, compared with 42.9 percent and 41.2 percent for college degree holders and junior/high school group, respectively.

However, the occupation of respondents is not clearly related to their level of understanding. Even the four staff members at Marks and Spencer who had received training about Fairtrade did not fully answer the questions correctly: only three of them had a moderate understanding and one had a good understanding of Fairtrade principles. Only those respondents employed in industries directly exposed to Fairtrade, such as a coffee maker, café owner, coffee bean supplier and coffee buyer, had a good level of understanding.

The ages of the responses were categorised into two demographic groups: those born after 1979 (one-child generation) and those born before 1980. Table 3 shows a slight trend towards older respondents having a greater understanding of Fairtrade than younger respondents. In fact, 68.6 percent of older respondents provided correct answers to at least half of the Fairtrade principle questions, compared with 53.9 percent for the younger group.It is probably that older respondents have had more exposure to concepts like Fairtrade: all of the older respondents who had a good or complete understanding of Fairtrade had come into contact with it travelling in cities such as London or Hong Kong or through Fairtrade stores in Chinese cities. Overall however, the survey revealed that the most common mechanisms through which respondents were made aware of Fairtrade were friends, newspapers or the internet: only a small proportion had learnt about it through employers or training, or travel.

\section{Willingness to Pay for Fairtrade Goods}

The respondents' willingness to pay a premium for Fairtrade goods is summarised in Table 4. The most commonly chosen premium for all levels of understanding, apart from the group with complete understanding, is 5-10 percent. In fact over 60 percent of respondents would pay an extra 10 percent, and a further 20 percent would pay an extra15percent, making up over 80 percent of the sample. The group with a complete understanding all chose a premium of 16-20 percent, consistent with the general assumption that a greater understanding of Fairtrade leads to a greater willingness to pay for Fairtrade goods. These results suggest that consumers need to reach a much more well-rounded understanding of Fairtrade before they feel compelled to accept paying a higher premium for goods. The Chinese have a slightly lower preference to their UK counterparts, who would usually pay $10-15 \%$ more for Fairtrade tea or coffee at the supermarket (Fairtrade Foundation, 2005).

Income level was tested to see if it was a factor that influenced respondents' willingness to pay a premium for Fairtrade goods. A cross tabulation was conducted between the two variables and the results revealed that a premium of 5-10percent was the most popular premium to pay for all income levels (see Table 5). It is not necessarily true that the higher the income, the higher the premium the customers are willing to pay. Over 37 percent of both the below average income (annual income between 30,000 to 50,000 yuan) and middle income groups (income level between 80,001-150,000 yuan) were willing to pay a premium of over 15 percent. However, respondents from the highest income group (income over 150,000 yuan) were more likely to want to pay a smaller premium, closer to 15percent or less. As discussed above, it is the level of awareness and understanding that is the key determinant of the level of willingness to pay.

The question of willingness to pay may be a redundant question for the time being for tea or coffee consumers in Shanghai and Suzhou given that Fairtrade tea and coffee are priced mid-range in both markets. Packets of tea in Shanghai supermarkets are priced anywhere between 3 yuan $(\$ 0.40)$ and 130 yuan $(<\$ 20)$ (Carrefour), whereas Fairtrade tea bags are priced at 25 yuan ( $\$ 4)$ for 25 teabags at Marks \& Spencer. Coffee is a trendy, new market for young people and all western café chains charge the same for coffee (Costa, Starbucks, Marks \& Spencer) 25 yuan for a regular latte - regardless of whether it is Fairtrade or not. The relative price of Fairtrade tea and coffee in Shanghai and Suzhou may influence respondents' attitudes towards willingness to pay a premium for these goods; however the extra cost of Fairtrade products in the Chinese case is not substantial. For example, a 
10 percent increase of 2.5 yuan $(\$ 0.35)$ on a cup of coffee worth 25 yuan is not significant for an average income earner $(50,000$ yuan/year) in our case study cities.

In such market conditions where both the level of awareness and level of willingness to pay are low, Fairtrade stores have to adjust their strategy to survive. The Fairtrade shop owners interviewed informed us that they did not charge extra for Fairtrade goods. While large retail chains are able to absorb the added costs of production of Fairtrade goods, smaller shops struggle with the added costs. This poses the question: who should cover the extra costs of production? One interviewee, who was a coffee supplier and buyer, felt that middlemen (wholesalers) should cover the premium and not consumers, as they are the ones reaping large profits at the expense of small producers.

The willingness to pay for Fairtrade goods is also dictated by marketing factors. One respondent commented that China is a mature tea market: promoting Fairtrade tea would be difficult. Another commented that quality and taste are key, as savvy Chinese tea drinkers would need to be tempted away from their usual purchases. However, coffee is a newly emerging market amongst trendy, young Chinese and such principles as ethical production and consumption may attract these consumers.

\section{Discussion and Concluding Remarks}

Fairtrade is a new concept in China. Fairtrade products are available only in a handful of cities. Given the low levels of exposure, awareness of Fairtrade and understanding of fair trade principles are low. Among the four key dimensions of the Fairtrade concept, Chinese consumers have a better understanding of environmental sustainability, but a very poor understanding of community empowerment. This may be explained by the fact that community empowerment itself is a relatively new and emerging concept in China. In contrast, environmental campaigns and awareness of environmental issues have long been promoted through various media both by the government and NGOs in China (Chen \& Jim, 2010; Zhai \& Suzuki, 2008; Shen, 2008; Jim \& Chen, 2006). Extensive research has also been conducted on the dangers of overutilization of chemical fertilizer and pesticides in agriculture and the willingness to pay for certified safe foods (Xu \& Wu, 2010). Promoting this knowledge in the public domain would contribute to Chinese consumers' understanding of environmentally sustainable farming.

Socioeconomic factors such as education and age do influence respondents' awareness and understanding of Fairtrade. More educated and older respondents seem to have a higher level of understanding and awareness. However, considering that overall levels of awareness are low, the Fairtrade market in China needs to focus on deepening consumers' understanding to motivate them to buy Fairtrade goods. Even respondents who had received training about Fairtrade through Marks and Spencer did not display a complete understanding of the concept: knowledge of the label alone is not enough to compel people to act. It appears that consumers need quite a complete and well-rounded understanding of the issues associated with Fairtrade in order to compel them to participate and buy goods.

The willingness to pay of the consumers directly reflects their level of understanding. Generally, consumers will choose to pay between 5-10 percent. The level of willingness to pay extra is not closely associated with income level. In fact, the richest group was still only willing to pay the lower premium. The average income and middle class consumers in China may be slightly more empathetic than their more affluent counterparts. This study did find that a higher level of awareness and understanding is associated with willingness to pay a higher premium.

It appears that Chinese consumers are at the beginning of MPG's model: they are moving out of the 'unaware' phase into the 'aware' phase and need a lot of input into the 'increasing knowledge and understanding' phase in order to motivate them to buy goods. However, the consumers surveyed displayed a good understanding of environmental sustainability and approximately half recognised that a fairer distribution of profits needs to be directed towards poorer producers, regardless of whether they had heard of Fairtrade or not. This reflects an opportunity for increased market share for Fairtrade in China.

Further in depth research into consumers' attitudes towards Fairtrade across a broader cross-section of consumers will reveal further information on the willingness to participate in consumption of Fairtrade goods in China. Consumers generally require a broad knowledge of the issue before they are willing to change their behaviour. Survey respondents were educated enough to understand their role as consumers in the market and are therefore ready to participate in such a concept, as demonstrated by those who have been exposed, whether in China or overseas, showing a level of understanding that is sufficient to compel them to act. At present, however, most Chinese lack such opportunities. 


\section{References}

Auger, P., Burke, P., Devinney, T. \& Louviere, J. (2003). What Will Consumers Pay for Social product Features. Journal of Business Ethics, 42, 281-304. http://dx.doi.org/10.1023/A:1022212816261

AdÁstous, A. \& Mathieu, S. (2008). Inciting Consumers to Buy Fairly Traded Products: A Field Experiment. Journal of Consumer Marketing, 25 (3), 149-157.

Castaldo, S., Perrini, F., Misani, N. \& Tencati, A. (2009). The Missing Link between Corporate Social Responsibility and Consumer Trust: The Case of Fair Trade Products. Journal of Business Ethics, 84, 1-15. http://dx.doi.org/10.1007/s10551-008-9669-4

Chen, Wendy Y. \& C. Y. Jim. (2010). Resident Motivations and Willingness-to-Pay for Urban Biodiversity Conservation in Guangzhou (China). Environmental Management, 45 (5), 1052-1064.

Doran, C. (2009). The Role of Personal Values in Fairtrade Consumption. Journal of Business Ethics, 84, 549-563. http://dx.doi.org/10.1007/s10551-008-9724-1

Doran, C. (2010). Fairtrade Consumption: In Support of the Out-Group. Journal of Business Ethics, 95, $527-541$. http://dx.doi.org/10.1007/s10551-010-0437-x

Fairtrade Association of Australia \& New Zealand. (2011). About Us Website. [Online] Available: www.fta.org.au/about

Fairtrade Foundation. (2011). Trade White Paper - Call for Evidence. [Online] Available: www.fairtrade.org.uk/resources/default.aspx

Fairtrade Foundation. (2008). The Fairtrade Mark: Core Standards and Practices Behind Fairtrade Labelling. [Online] Available: www.fairtrade.org.uk/resources/default.aspx

Fairtrade Foundation. (2005). Fairtrade Foundation: Review of UK Supply Chain, Returns to Producers and Retail Margin Issues. [Online] Available: www.fairtrade.org.uk/resources/default.aspx

Fairtrade Hong Kong Foundation. (2011). About Us. [Online] Available: http://www.fairtradehk.org/?page_id=230\&lang=en

Fairtrade Labelling Organisation International. (2011). History of Fairtrade. [Online] Available: www.fairtrade.net/history_of_fairtrade.0.html

Freestone, O. \& McGoldrick, P. (2008). Motivations of Ethical Consumers. Journal of Business Ethics, 79, 445-467. http://dx.doi.org/10.1007/s10551-007-9409-1

The Green Room. (2010). List of stores that stock Fairtrade in China. [Online] Available: http://www.greenroomchina.com/FairTrade_08.html

Jim, C. Y. \& W. Y. Chen. (2006). Perception and attitude of residents towards urban green spaces in Guangzhou (China). Environmental Management, 38, 338-349. http://dx.doi.org/10.1007/s00267-005-0166-6

Li, Hong. (2007). Establishing a Western Coffee Shop Chain in China, Master Thesis, Faculty of Business Adminitration, Simon Fraser University.

MPG International. (2004). Sustainable Motivation, Attitudinal and Behavioural Drivers for Action. [Online] Available: http://www.mpgintl.com/rm.html

Nelson, V. \& Pound, B. (2009). The Last Ten Years: A Comprehensive Review of the Literature on the Impact of Fairtrade. Natural Resource Institute, Greenwich University. [Online] Available: http://www.fairtrade.org.uk/resources/natural_resources_institute.aspx

Shen, Junyi. (2008). Understanding the determinants of consumers' willingness to pay for eco-labeled products: An empirical analysis of the China Environmental Label. OSIPP Discussion Paper \# 08E001, Osaka School of International Public Policy, Osaka University.

Stokes, R. C. (1985). The Effects of Price, Package Design, and Brand Familiarity on Perceived Quality. In J Jacoby \& J Olson (Eds.). Perceived Quality (pp. 233-246). Lexington: Lexington Books.

Watterson, W. (2008). Principle \& Pragmatism: The New Zealand Fairtrade Consumer and Their Perspectives on the Future of Fairtrade. [Online] Available: http://researcharchive.vuw.ac.nz/handle/10063/1015

Witkowski, T. (2005). Fair Trade Marketing: An Alternative System for Globalisation and Development. Journal of Marketing Theory and Practice, 13 (4), 22. 
Wynne, S. (2008). The Challenges of Marketing Fairtrade. [Online] Available: http://www.sandywynne.com/thesis.pdf

$\mathrm{Xu}$, Lingling. \& Linhai Wu. (2010). Food safety and consumer willingness to pay for certified traceable food in China. Journal of the Science of Food and Agriculture, Special Issue: 14th World Congress of Food Science and Technology, 90 (8), 1368-1373.

Zhai, Guofang \& Takeshi Suzuki. (2008). Public willingness to pay for environmental management, risk reduction and economic development: Evidence from Tianjin, China. China Economic Review, 19 (4), 551-566. http://dx.doi.org/10.1016/j.chieco.2008.08.001

Table 1. Total frequency of responses for each level of understanding including frequency of responses for each Fairtrade question

\begin{tabular}{|c|c|c|c|c|c|}
\hline Groups & $\begin{array}{l}\text { Q.5 Fair } \\
\text { pricing }\end{array}$ & $\begin{array}{l}\text { Q.6 Working } \\
\text { conditions }\end{array}$ & $\begin{array}{c}\text { Q.7 } \\
\text { Empowering } \\
\text { communities }\end{array}$ & $\begin{array}{c}\text { Q.8 } \\
\text { Environmental } \\
\text { sustainability }\end{array}$ & Total \\
\hline $\begin{array}{c}\text { Total respondent } \\
/ \%\end{array}$ & $\begin{array}{c}51 / 100 \% \\
(50 \%)\end{array}$ & $\begin{array}{c}42 / 100 \% \\
(41 \%)\end{array}$ & $\begin{array}{c}16 / 100 \% \\
(16 \%)\end{array}$ & $\begin{array}{c}78 / 100 \% \\
(76 \%)\end{array}$ & $103 / 100 \%$ \\
\hline No Understanding & $\begin{array}{l}0 / 0 \% \\
(0 \%)\end{array}$ & $\begin{array}{l}0 / 0 \% \\
(0 \%)\end{array}$ & $\begin{array}{l}0 / 0 \% \\
(0 \%)\end{array}$ & $\begin{array}{l}0 / 0 \% \\
(0 \%)\end{array}$ & $5 / 4.9 \%$ \\
\hline $\begin{array}{c}\text { Limited } \\
\text { Understanding }\end{array}$ & $\begin{array}{c}6 / 11.8 \% \\
(15 \%)\end{array}$ & $\begin{array}{l}4 / 9.5 \% \\
(10 \%)\end{array}$ & $\begin{array}{c}2 / 12.5 \% \\
(5 \%)\end{array}$ & $\begin{array}{c}27 / 34.6 \% \\
(69 \%)\end{array}$ & $39 / 37.9 \%$ \\
\hline $\begin{array}{c}\text { Moderate } \\
\text { Understanding }\end{array}$ & $\begin{array}{c}20 / 39.2 \% \\
(63 \%)\end{array}$ & $\begin{array}{c}16 / 38.1 \% \\
(50 \%)\end{array}$ & $\begin{array}{c}5 / 31.3 \% \\
(16 \%)\end{array}$ & $\begin{array}{c}24 / 30.8 \% \\
(75 \%)\end{array}$ & $32 / 31.1 \%$ \\
\hline $\begin{array}{c}\text { Good } \\
\text { Understanding }\end{array}$ & $\begin{array}{c}23 / 45.1 \% \\
(92 \%)\end{array}$ & $\begin{array}{c}20 / 47.6 \% \\
(80 \%)\end{array}$ & $\begin{array}{c}7 / 43.8 \% \\
(28 \%)\end{array}$ & $\begin{array}{c}25 / 32.1 \% \\
(100 \%)\end{array}$ & $25 / 34.3 \%$ \\
\hline $\begin{array}{c}\text { Complete } \\
\text { Understanding }\end{array}$ & $\begin{array}{l}2 / 3.9 \% \\
(100 \%)\end{array}$ & $\begin{array}{l}2 / 4.8 \% \\
(100 \%)\end{array}$ & $\begin{array}{l}2 / 12.5 \% \\
(100 \%)\end{array}$ & $\begin{array}{l}2 / 2.6 \% \\
(100 \%)\end{array}$ & $2 / 1.9 \%$ \\
\hline
\end{tabular}

Note: data in brackets is the percentage of correct answers of the Fairtrade question for each level of understanding.

Table 2. Education levels for the five levels of understanding

\begin{tabular}{|c|c|c|c|}
\hline Group & $\begin{array}{c}\text { High school or } \\
\text { under }\end{array}$ & College & $\begin{array}{c}\text { Bachelor or } \\
\text { above }\end{array}$ \\
\hline No understanding & $2 / 11.8 \%$ & $2 / 9.5 \%$ & $1 / 1.7 \%$ \\
\hline Limited understanding & $8 / 47.0 \%$ & $10 / 47.6 \%$ & $19 / 32.2 \%$ \\
\hline Moderate understanding & $6 / 35.3 \%$ & $4 / 19.1 \%$ & $21 / 35.6 \%$ \\
\hline Good understanding & $1 / 5.9 \%$ & $5 / 23.8 \%$ & $16 / 27.1 \%$ \\
\hline Complete understanding & $0 / 0 \%$ & $0 / 0 \%$ & $2 / 3.4 \%$ \\
\hline Total & $17 / 100 \%$ & $21 / 100 \%$ & $59 / 100 \%$ \\
\hline
\end{tabular}

Note: among 103 respondents, 6 of them did not provide their education information. 
Table 3. Relationship between age and the five levels of understanding

\begin{tabular}{|c|c|c|c|}
\hline Age Demographic & $\begin{array}{c}\text { Younger Group } \\
\text { (born after 1979) }\end{array}$ & $\begin{array}{c}\text { Older Group } \\
\text { (born before1980) }\end{array}$ & Didnot provide age \\
\hline Total & $65 / 100 \%$ & $29 / 100 \%$ & $9 / 100 \%$ \\
\hline No understanding & $3 / 4.6 \%$ & $2 / 6.9 \%$ & $0 / 0 \%$ \\
\hline Limited & $27 / 41.5 \%$ & $7 / 24.1 \%$ & $5 / 55.6 \%$ \\
\hline Moderate & $20 / 30.8 \%$ & $10 / 34.5 \%$ & $2 / 22.2 \%$ \\
\hline Good & $14 / 21.5 \%$ & $9 / 31.0 \%$ & $2 / 22.2 \%$ \\
\hline Complete & $1 / 1.6 \%$ & $1 / 3.5 \%$ & $0 / 0 \%$ \\
\hline
\end{tabular}

Table 4. Willingness to pay for the five groups of understanding

\begin{tabular}{|c|c|c|c|c|c|c|c|}
\hline Price Premium & $0-5 \%$ & $5-10 \%$ & $11-15 \%$ & $16-20 \%$ & $21-25 \%$ & $>25 \%$ & Total \\
\hline \multirow{2}{*}{ No understanding } & $0 /$ & $4 /$ & $0 /$ & $1 /$ & $0 /$ & $0 /$ & $5 /$ \\
& $0 \%$ & $80.0 \%$ & $0 \%$ & $20.0 \%$ & $0 \%$ & $0 \%$ & $100 \%$ \\
\hline Limited & $4 /$ & $17 /$ & $7 /$ & $6 /$ & $2 /$ & $1 /$ & $37 \% /$ \\
Understanding & $10.8 \%$ & $46.0 \%$ & $18.9 \%$ & $16.2 \%$ & $5.4 \%$ & $2.7 \%$ & $100 \%$ \\
\hline Moderate & $7 /$ & $13 /$ & $7 /$ & $2 /$ & $1 /$ & $2 /$ & $32 /$ \\
Understanding & $21.9 \%$ & $40.6 \%$ & $21.9 \%$ & $6.3 \%$ & $3.1 \%$ & $6.2 \%$ & $100 \%$ \\
\hline Good & $7 /$ & $9 /$ & $6 /$ & $2 /$ & 0 & $1 /$ & $25 /$ \\
Understanding & $28.0 \%$ & $36.0 \%$ & $24.0 \%$ & $8.0 \%$ & $/ 0 \%$ & $4.0 \%$ & $100 \%$ \\
\hline Complete & $0 /$ & $0 /$ & $0 /$ & $2 /$ & $0 /$ & $0 /$ & $2 /$ \\
Understanding & $0 \%$ & $0 \%$ & $0 \%$ & $100 \%$ & $0 \%$ & $0 \%$ & $100 \%$ \\
\hline Total & $18 /$ & $43 /$ & $20 /$ & $13 /$ & $3 /$ & $4 /$ & $101 /$ \\
& $17.8 \%$ & $42.5 \%$ & $19.8 \%$ & $12.9 \%$ & $3.0 \%$ & $4.0 \%$ & $100 \%$ \\
\hline
\end{tabular}

Note: two did not provide a response.

Table 5. Crosstabulation of willingness to pay vs. income level

\begin{tabular}{|c|c|c|c|c|c|c|c|}
\hline $\begin{array}{c}\text { Income } \\
\text { Group }\end{array}$ & $<5 \%$ & $5-10 \%$ & $11-15 \%$ & $16-20 \%$ & $21-25 \%$ & $>25$ & Total \\
\hline $\begin{array}{c}\text { Low income } \\
(<30000)\end{array}$ & $7 /$ & $23 /$ & $11 /$ & $6 /$ & $1 /$ & $1 /$ & $47 \% /$ \\
\hline $\begin{array}{c}\text { Average income } \\
(30001-50000)\end{array}$ & $14.3 \%$ & $46.9 \%$ & $22.4 \%$ & $12.2 \%$ & $2.1 \%$ & $2.1 \%$ & $100 \%$ \\
\hline Just above average & $3 /$ & $2 /$ & $2 /$ & $2 /$ & $0 /$ & $1 /$ & $8 /$ \\
$(50001-80000)$ & $21.4 \%$ & $35.7 \%$ & $28.6 \%$ & $14.3 \%$ & $0 \%$ & $0 \%$ & $14 / 100 \%$ \\
\hline Middle income & $1 /$ & $4 /$ & $0 /$ & $1 /$ & $1 /$ & $1 /$ & $8 / 100 \%$ \\
$(80001-150000)$ & $12.5 \%$ & $50 \%$ & $0 \%$ & $12.5 \%$ & $12.5 \%$ & $12.5 \%$ & \\
\hline High income & $3 /$ & $6 /$ & $1 /$ & $0 /$ & $0 /$ & $1 /$ & $11 / 100 \%$ \\
$(>150000)$ & $27.3 \%$ & $54.5 \%$ & $9.1 \%$ & $0 \%$ & $0 \%$ & $9.1 \%$ & \\
\hline Total & $15 /$ & $40 /$ & $18 /$ & $11 /$ & $2 /$ & $4 /$ & $92 \%$ \\
& $16.7 \%$ & $44.5 \%$ & $20.0 \%$ & $12.2 \%$ & $2.2 \%$ & $4.4 \%$ & $100 \%$ \\
\hline
\end{tabular}

Note: 2 did not provide their preference; \#11 did not provide income. 


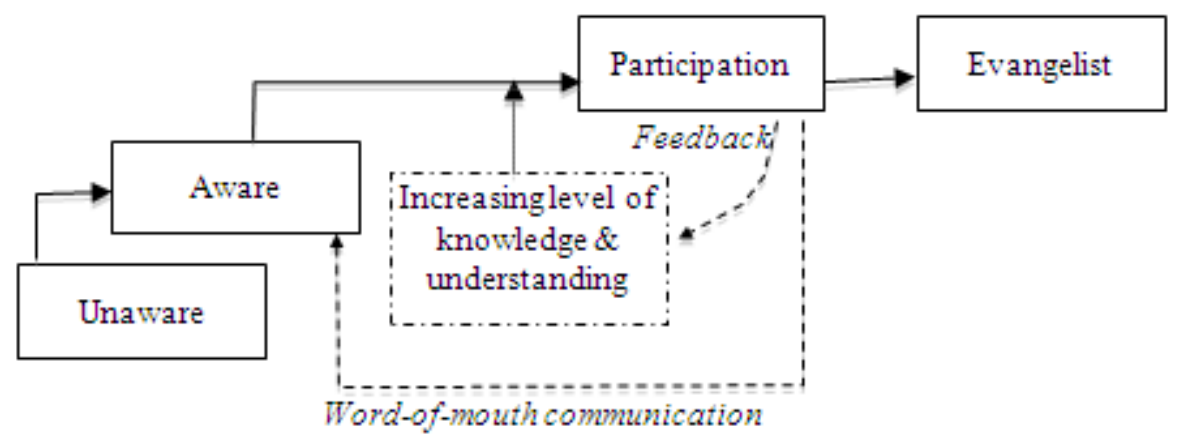

Figure1. Levels of awareness and knowledge that result in participation in ethical activity Source: Modified MPG International, 2004, page 5. 